\title{
LYPLA1 wt Allele
}

National Cancer Institute

\section{Source}

National Cancer Institute. LYPLA1 wt Allele. NCI Thesaurus. Code C104625.

Human LYPLA1 wild-type allele is located in the vicinity of 8q11.23 and is approximately 56

$\mathrm{kb}$ in length. This allele, which encodes acyl-protein thioesterase 1 protein, is involved in regulating the level of lysophospholipids in membranes. 